\title{
Management of insect pests and diseases of tomato in farmer's field through IPDM practices
}

\author{
Noorulla Haveri*, K.S. Nagaraja and K. Thulasiram \\ ICAR-Krishi Vigyan Kendra, Kolar (Karnataka) India
}

\section{ARITCLE INFO}

Received : 21.01 .2019

Revised : 15.03 .2019

Accepted : 21.03 .2019

\section{KEY WORDS :}

Integrated insect pests, Diseases

management, Frontline

demonstration (FLD),

Tomato
*Corresponding author:

Email : noorulla4153@yahoo.com

\begin{abstract}
Integrated management practices in tomato against major insect pests and diseases were demonstrated by ICAR-Krishi Vigyan Kendra, Kolar, Karnataka (India) through Frontline demonstration (FLD) in the selected tomato farmer's fields during 2014-15, 2015-16 and 2018-19. The demonstrated technologies found most effective in insect pest management and resulted in reduction in mean white fly incidence (0.99/leaf), thrips incidence (0.51/leaf), serpentine leaf minor incidence ( 1.09 mines/leaf), red mite incidence (0.69/leaf), fruit borer incidence (1.51\%) and American pin worm incidence $(3.20 \%)$ as compared to farmer's practice plots. Similar effect was noted on disease management wherein demonstrated plots recorded least mean late blight incidence (9.79 PDI), early blight incidence (5.77 PDI), tomato leaf curl incidence (3.13\%) and tomato spotted wilt incidence $(1.31 \%)$ compared to farmer's practice plots. These insect pests and diseases are the major constraints in tomato production and affect the yield to a greater extent. The average increase in mean tomato yield in demonstration plots was $7.73 \mathrm{t} / \mathrm{ha}(16.65 \%)$ over farmers practice. Further, upon adoption of integrated management practices, growers have realized higher mean net returns (135917 Rs./ha) and benefit cost ratio (1.76) as against the farmers practice ( 89744 Rs./ha and 1.49 of net returns and benefit cost ratio, respectively). The difference in the yield was due to adoption of integrated insect pests and disease management practices by the tomato farmers as demonstrated by the KVK. Thus, the demonstrated technologies proved to be highly effective in insect pests and diseases management compared to the existing farmers practice for tomato farmers of the district.
\end{abstract}

How to view point the article : Haveri, Noorulla, Nagaraja, K.S. and Thulasiram, K. (2019). Management of insect pests and diseases of tomato in farmer's field through IPDM practices. Internat. J. Plant Protec., 12(1) : 67-71, DOI : 10.15740/HAS/IJPP/12.1/67-71, Copyright@ 2019: Hind Agri-Horticultural Society. 